\title{
THE UTILIZATION OF THE INTERNET RESOURCES FOR ENHANCING THE SELF-STUDY OF VIETNAMESE STUDENTS IN IMPROVING THEIR ENGLISH COMPETENCE
}

\author{
Bui Thi Kieu Giang ${ }^{1,}$ Vu Van Tuan ${ }^{2}$ \\ ${ }^{1}$ Thai Nguyen University of Agriculture and Forestry, Viet Nam \\ ${ }^{2}$ Hanoi University of Business and Technology, Vietnam \\ buikieugiangphd@gmail.com \\ vuvantuanphd@gmail.com
}

\begin{abstract}
This paper examines the importance of the utilization of the Internet resources for enhancing the self-study of Vietnamese students in improving their English competence. This descriptive study highlights the role of the teachers using the ICT to monitor the process of self-directed English acquisition and analyze the necessity of employing the social networking sites as the main tools in improving the students' English competence. The data was collected through the questionnaires done by both 22 teachers and 74 students randomly chosen. Descriptive quantitative and qualitative analysis were employed to analyze the data collected by using IBM SPSS statistical software. As a whole, the findings reveal that the accessibility and ability to use the social networking sites of both the teachers and the students are very high. However, the teachers failed to support the students in the self-directed English learning utilizing the Internet resources. There is a need to change the curriculum and to retrain the teachers in order to take the best advantages of the digital learning and teaching Second Language Acquisition) (SLA).
\end{abstract}

Keywords: Industry 4.0; Industrial Internet; digital technologies; social development trend; digital learning

\section{INTRODUCTION}

In the past few years, the development of the industrial revolution has changed the whole world, making the world become flat. Stated clearly by Klaus Schwab (2016), four stages in the industrial revolution were mentioned in the book but noticeably the fourth industrial revolution or simply called industry 4.0 or industrial internet. This term was coined at the Hannover Fair in 2011 to point out how Industry 4.0 would revolutionize the global value chains by creating a world that virtual and physical systems of manufacturing globally are flexibly combined. Although Industry 4.0 affects many services and logistics sectors, the study concentrates on changes in the core areas of distance education, especially focuses on the self-study of Vietnamese students in acquiring English using the digital technologies, as this has a high, almost unique significance in Vietnamese education, especially in the scheme on "Teaching and learning a foreign language in the national education system the period 2008-2020". This scheme also concentrates on using the digital technologies as the main tools in the process of innovating the quality of education, particularly the selfstudy of learners in SLA. Most of universities and education centers have conversed their syllabuses from fixed-yearly system to credit system backing on the digital technologies. In 2008, the Ministry of Education and Training of Vietnam (MOET) launched the plan for a national foreign language project, Project 2020 for short, which target to "renovate thoroughly the tasks of teaching and learning foreign languages within the national educational system in the period 2008-2020.", and strengthened the role of industrial internet.

Industry 4.0 has affected the Vietnamese educational system. According to a snapshot of Vietnamese country's key digital statistical indicators released in January 2017 by Hootsuite organization, 50.05 million people over 94.93 total population of Vietnamese penetrated the Internet, accounting for 53\%. This figure proves that the Internet facilities in Vietnam can meet the demand of accessing all sources that support English learners who have little chances to use English outside schools. However, not many studies have conducted on the importance of the utilization of the industrial Internet or Information and Communication Technologies (ICT) to the self-study of students in general and English learning in particular. This study will bring about the further successive studies, cementing the role of the Industry 4.0 on education, namely the self-study of English learners with digital technologies. 
The Southeast Asian Ministers of Education Organization (SEAMEO) Secretariat (2010) when releasing a Report: Status of ICT Integration in Education in Southeast Asian Countries supposed that digital learning would incorporate ICT in all educational systems. Thus, it is essential for educators to catch up with the spirit of the time and update themselves to learn, work, and teach with the ICT innovations, which are replacing the traditional methods. This is considered as a basis for the proposal for e-learning development in not only education in Southeast Asian Countries but also in other countries in the world.

Chan and his partners (2011) did a research on media in foreign language teaching and learning. In their study, they tried to find out whether media influenced learning. The conclusion was in favour of using digital technologies in education. They, however, only emphasized the role of the media as a medium of supporting teaching and learning in classrooms but it did not invoke the self-study of English learners with digital technologies.

Pfeiffer (2015) mentioned about the effects of Industry 4.0 on vocational education and training. His study only concentrated on changes in the main fields of industrial manufacturing work, and paid attention to the system of dual vocational education and training, unfortunately, he did not investigate the field of the selfstudy of learners in acquiring English backing on the industrial internet. Besides, Weller (2005) focused on the impact of delivering learning on the Internet, he also pointed out the significant impact of the Internet on online education. Pritchard (2007) ascertained that there were certain features of ICT which could have a great influence on teaching and learning. Said and his four colleagues (2015) investigated the nature of student group online interactions in learning with ICT for education, the finding revealed that the incorporation of online collaborative learning could result in the facilitation of the students and students' group learning process and potential constraints from the technology or the lack of social and verbal cues which could lead to different working methods of communication and different styles of interactions and student's involvement.

In Vietnam, many concerns have been focused on the role of ICT in education. Dr. Vu N. Hoang (2015) emphasized the role of education reform during the international integration, which requires each student to use the ICT to enrich themselves, and overcome the language barriers by applying technological advances in machine translation, automatic translation, and direct translation. Besides, Long (2016) carried out a research on IT application in foreign language education in Vietnam. He strongly suggested bringing IT into the classroom and into the training process. Furthermore, on $26^{\text {th }}$ Aug 2016, Minister of MOET - Nha signed Directive No.3031/CT-BGDDT on the main task of the school year 2016 - 2017 of education, in which he focused on improving the quality of teaching foreign languages, especially English at all levels of education and training by standardizing the contingent of foreign language teachers to meet the requirement to implement a 10-year foreign language program for general education, assisting the teacher training colleges and pedagogic colleges to train and retrain foreign language teachers in new foreign language programs. This directive is supportive for the weaknesses of the national foreign language project, project 2020.

Thus, this study aimed to investigate the effects of using the Internet resources for enhancing the self-study of Vietnamese students in improving their English competence by answering the following questions:

1. What is the ability to use the Internet and attitude of English learners towards the self-study with the assistance of the industrial internet?

2. Do teachers encourage and support English learners to enhance their self-study of English employing the virtual reality?

3. How can teachers of English and learners use the Internet resources to be better at learning English as a second language?

\subsection{Significance of the study}

There are two goals of the study. Firstly, this study is done in order to encourage the self-study of Vietnamese learners in an effort to use English as a second language with the help of digital technologies. Therefore, the findings of this study will advance their attitudes towards the self-study in second language acquisition via Industry 4.0. Secondly, this study enlightens the role of effectively using ICT in teaching English and getting in touch between teachers and English learners via the virtual reality. This requires 
teachers to update themselves with the internet resources to help their students better at SLA to catch up with the social development trend.

\section{LITERATURE REVIEW}

\subsection{Theories in Second Language Acquisition}

The development of theories on SLA dates back from pre-20 $20^{\text {th }}$ century which emphasized the role of Grammar-Translation method. Remarkably, early 1900s, Audio-lingual and Direct methods were dominant in SLA with two well-known linguists' preference, namely; Bloomfield (1930s) and Fries (1940s). After that, during 1940s and 1950s, the Behaviorist Theory or Stimulus Response Reinforcement Behaviorist theory was highly supported by Skinner. The next theory, dominated during 1960s and 1970s, was the Universal Grammar, Language Acquisition Device (LAD) which was introduced by the linguist Chomsky, preceding by Krashen. The emergence of digital technologies appeared in the classrooms was made known in the 1980s and 1990s with Information Processing Models, which was in favour of Anderson (1983), and McLaughlin (1990). The last theory that has been mentioned from the 1990s until now is Social Interactionism, remarkably by a Soviet psychologist, Semyonovich and an educational psychologist and applied linguist, Snow. Overviewing the development of theories in SLA, it is concluded that the educational trend is highly affected together with the changes of social civilization.

\subsection{The science of teaching}

Concerning with the utilization of teaching ESL using digital learning, it is useful to see the science of teaching. According to Marzano (2003b) in his text "What Works in Schools", he introduced a framework for understanding the features of effective teachers within the effective schools. There are three components of Effective Classroom Pedagogy which creates the effective classroom pedagogy. Three general features of effective teaching are indicated in that framework such as

1. Use of effective instructional strategies;

2. Use of effective classroom management strategies; and

3. Effective classroom curriculum design strategies.

From this model, it can be seen that when applying digital learning, instructional strategies and classroom management strategies need strong attention to get the learners into the effective learning process. By the way, it is advisable to mention something about the benchmarks in science teaching.

Parkay et al (2010) stated that Benchmarks in Science Teaching (BST) are specific content criteria of what students are supposed to comprehend, know, and do at certain grade levels. Benchmarks can be used to develop performance standards, assessment tools, textbooks and instructional plans. "Benchmarks" and "standards" might be considered to be the same; however, Benchmarks are considered as more general goal statements while standards are regarded as more specific.

\subsection{The science of learning}

The cognitive processes account for how and why we learn belong to the science of learning. Throughout the history of education, theoretical changes in psychology have dealt with these cognitive processes in different ways, which lead to change the study of daily learning. As an evidence, behaviorists highly influenced the popularity of late-twentieth to mid-twentieth century education with their arguments that measured observable behaviors and treated mental processes together with the mind as a black box which was conducted by empirical psychological research.

Nevertheless, together with the behaviorist and other changes in the mid-twentieth century, studies clearly stated that learning could happen without either strict conditioning or external reinforcement. For example, after one experience, learning often took place, as in an animal that gets sick after eating something and refuses to eat that food again (one-trial learning). Researches have shown that people used language implicitly; it meant learning could happen when one person watched another do something. In fact, people could learn something new only by careful supervision from the others. The human brain was self-adapting, flexible, and self-taught. Thus, cognitive revolution represents a paradigm shift from a behaviorist perspective to a cognitive perspective. The focus of this paper is to find out the effects of using internet resources to strengthen a learner-centered approach which supports the way in which learners can benefit from the self-study of ESL.

\subsection{Virtual Learning Environment}


Kumar (1998) defined the Virtual Learning Environment (VLE) as an integrated multimedia teaching environment designed in principle so that students can do everything that takes place in traditional schools, but do so through the internet. From this definition, VLE is a self-contained, web-based system that do not need any other technology to host classes. Thanks to an HTML internet browser, learners can access the Internet no matter wherever they are as long as they have the Internet connection. As cited by Goldber and McKhann (2000), VLE incorporates audio, animation, video, and text in a multimedia computer environment. Educause Center for Applied Research (2003) acknowledged that the VLE is the core component of distance learning or blended learning instruction environments. The online classes involve the interaction between an instructor and a student or a group of students depending on the Internet access. The instructor posts necessary course materials or any task, so students have to update the information regularly. A variety of different techniques would be applied to access the students' improvement.

It could be argued that science and other technical subjects need the laboratory requirements so they are more difficult to teach through the Internet. Roux, and Evans (2011) said that virtual labs are as effective as classroom laboratory settings for teaching students' concepts which facilitate them with demonstration in the actual laboratory research. Some experiments seem to work better if they are carried out by the virtual labs. With the learning ESL, graphical demonstrations can demonstrate better images that are hard to imagine.

\subsection{Technology enhanced learning}

It is true to say that technology-enhanced learning (TEL) software can play a role as a mediator between the student and the student's environment on the account that activity and interaction are essential in learning processes. Actually, the central aim of deeper and long-lasting learning experiences is to engage the students to learn actively.

With the effects of recent technology advances as well as industrial Internet, an innovative shift from purely knowledge-based learning to activity-based learning and training is considered. Interactive Web and multimedia technologies allow to carry on skills-oriented training in technology-enhanced learning environments. Pahl, and Kenny (2008), and Shimic (2008) emphasized the importance of technologyenhanced learning for learners who might have less time spending on regular classes. Ricardo, and Martın, and Crespo, and Mezcua (2010) did researches on education for students with disabilities with a wider range of assistive tools. They strongly encouraged the use of TEL for the disable. Similarly, Eamer (2010) concluded that the virtual classroom allows for a levelling of the playing field in that the absence of a shared physical space can potentially reduce the weight of cultural and linguistic hegemony. Charalabopoulou (2010) found out that the future versions of the courseware would be entirely on the Internet, they would include a set of additional tools and improved functionalities and they would exploit Web 2.0 tools and technologies in order to create an e-learning platform. Besides, Merino, and Lopez, and González (2010) believed that technologies adoption, learners' capabilities, technology uses in the educational process by teachers as well as students, or the selection of a methodology that complies with digital uses would be useful in education. Sherly, and Uddin (2010) proposed that Technology Enhanced Learning and Teaching (TELT) Model provides learning through collaborations and interactions with a framework for content development and collaborative knowledge sharing system as a supplementary for learning to improve the quality of education system. Similarly, Bonanno (2010) suggested that the Process-Oriented Model for Technology-Enhanced Learning was employed to implement a programme in TEL combining epistemology, pedagogy, and design principles with the help of digital tools.

\subsection{Using the internet for active teaching and learning}

The concept about active learning refers to the active involvement of students in the learning strategy. They are in the process of learning-by-doing so the result may turn out to be that active participation and knowledge construction are engraved of learners' mind. Interactivity, i.e. particular learner-content interaction, is the key aspect of technology-enhanced active learning. The role of integrating technology into the classroom activities is considered as an inseparable part of good teaching. In reality, active learning happens when instructional activities invoke students to do things and think about what they are involved.

The use of technology as a tool for teaching and learning in the classroom should create learning tasks that extend information retrieval to problem solving, encourage the deep processing of notions, increase student commitment with the subject matter, enhance teacher and student motivation for learning, and promote student-to-student and student-to-teacher interaction (Earle, 2002). 


\subsection{The Student Self-Study Attitude}

The development and ubiquity of the internet resources allow students to spend time positively for self-study outside classrooms. They also express positive attitudes about self-study outside the classrooms when their teachers supply them with motivational tools. Furthermore, they have a positive attitude about exploring a new method of study when their teacher communicates with them outside the classroom. Besides, they do not suffer from pressure from other learners in a negative way to participate in self-study activities outside the classroom.

Self-studying is also considered a valuable way to learn because learners have to challenge themselves with a new kind of knowledge. Technology plays an important role in providing them with assistance, drills a new skill or learns an entirely new concept. It is clear that internet resources are open to everyone, particularly SLA, and the best place for students to exploit their availability.

\section{METHODS}

\subsection{Research Design}

Descriptive method was employed with the assistance of using questionnaires and comparative techniques. The study described the respondents' habit, time, means of using the Internet resources for self-study. The purpose of the study was to find out what students exploit the websites for enhancing their English under the supervision of the teachers. Qualitative and quantitative methods are used in the questionnaires which are basing on the theory of Dörnyei (2010). This paper took advantage of using the survey questionnaires, so the findings would contribute to the efficiency of SLA Vietnamese learners.

\subsection{Respondents and sampling procedure}

The respondents of the study involved two kinds of participants, namely; teachers and students. The students were questioned by using the mailshots then shortlisted randomly among university students: namely Thai Nguyen University of Agriculture and Forestry, and Hanoi University of Business and Technology. In order to avoid bias sample, stratified random sampling was employed to proportionately allocate the number of respondents at each university with intended sample size. The participants were identified by draw lots in the smaller university and by random number key of a scientific calculator for the bigger university. Therefore, from the 81 population of the study, 74 were identified through the application of Slovin's formula (1960). Teachers were questioned by random selection, aslo using the mailshots with 22 repondents shortlisted.

\subsection{Research Instrument}

Basing on the ideas of Dörnyei (2010), the questionnaires, which were compiled by the authors, were designed into the three main parts, namely the time participants spending on the Internet, the time they spent on their study and how efficiently they contacted with their teachers or students. Using the Likert's scale (1932), the instrument tapped into the cognitive and affective components of attitudes of the respondents.

\subsection{Data collection}

The questionnaires were shot to the all emails of the respondents with the help of the administrative aides. At first both authors together compiled the questionnaires, then survey questionnaires were passed to the practitioners for content validation. After that pilot testing of the survey questionnaire was carried out to a group of students and teachers who were not intended to use as the respondents of this study to validate the strengths and weaknesses of the instrument. The experts were again consulted for the finalization of the questionnaire before the authors shot them via emails to the intended respondents. After receiving the outputs of the survey questionnaires from the respondents, the stratified sampling technique was applied to get the expected samples for the survey basing on the university population. The authors, together, treated the qualitative and quantitative data using the SPSS IBM v.23 to get the results.

\subsection{Data analysis}

The descriptive statistics particularly frequency counts, and percentages were employed in analyzing the time participants spent on the internet, and the time they spent on their study. T-test was used to compare between the frequency of contact between the teachers and students via the industrial internet.

\section{RESULTS}

The findings from the survey of the students

The gadgets, which students usually used in social networking, are laptops which account for 32 out of 74, equivalent to 43.2; then desktop 25 respondents, $33.8 \%$ and the last cellphone 17 samples, $2.35 \%$. For the place the students do social networking, it is their house mostly (58.1\%) then school (27\%) and Cyber Café 
14.95. The reason why they do social networking at home account for the internet speed in Vietnam which is quite good according to the report by Google Consumer Barometer, Jan 2017.

The Table 1 shows the frequency of the social networking sites being used by the students.

Table 1: The frequency of the social networking sites being used

\begin{tabular}{|c|c|c|}
\hline & Mean & Description \\
\hline Facebook & 3.74 & Often \\
\hline Twitter & 1.70 & Never \\
\hline LinkedIn & 1.97 & Seldom \\
\hline Google+ & 1.69 & Never \\
\hline Instagram & 2.74 & Sometimes \\
\hline Zalo & 3.65 & Often \\
\hline Skype & 2.07 & Seldom \\
\hline FB messenger & 4.14 & Often \\
\hline Youtube & 3.68 & Often \\
\hline Viber & 1.64 & Never \\
\hline Wechat & 1.41 & Never \\
\hline Yahoo & 1.38 & Never \\
\hline Line & 1.47 & Never \\
\hline General Weighted Mean & 2.41 & Sometimes \\
\hline
\end{tabular}

Legend

Scale Adjectival Description

$5(4.2-5.0) \quad$ Always

$4(3.5-4.2) \quad$ Often

$3(2.7-3.4) \quad$ Sometimes

$2(1.9-2.6) \quad$ Seldom

$1(1.0-1.8) \quad$ Never

From the finding in Table 1, it indicates that the student respondents highly visited some popular social networking sites, namely; FB messenger 4.14, Facebook 3.74, YouTube 3.68 and Zalo 3.65, which seems to be that the students are easy to access via the internet.

Again, the results in Table 1 reveal that the time that the students often check the internet is very astonished with $66.2 \%$ accessing the social networking sites at least once each day and $33.8 \%$ visiting more than 5 times a day. Furthermore, the length of time they spend on the internet is very high with $35.1 \%$ for 3-4 hours/ day and $8.1 \%$ for 30 minutes. Their attitude on using the Internet at school is quite noticeable. From the data, it is shown that the students often use the Internet during lunch breaks with $36.5 \%$, following that after school or extra activities for $33.8 \%$, when teacher allows for computer use $17.6 \%$ and remarkably during the class when the teacher is not watching is the least $12.2 \%$. This implies that these kinds of media help student respondents easily communicate with other people and access the Internet resources. However, they mostly use the Internet facility for the purpose that they can get connected with other people only for their business, not for the self-study in English.

The Table 2 reveals the activities that the student often do when they are online.

Table 2. Activities when going on the Internet

\begin{tabular}{lcc}
\hline & Mean & Description \\
\hline $\begin{array}{l}\text { How long do you stay online to do your study related work or } \\
\text { search study related information? }\end{array}$ & 2.39 & limited extent \\
How long do you stay online to watch online classes in English? & 1.88 & no extent \\
$\begin{array}{l}\text { How long do you stay online to chat, talk and meet with friends } \\
\text { and families in English? }\end{array}$ & 1.39 & no extent \\
$\begin{array}{l}\text { How long do you stay online to visit blogs and online } \\
\text { communities? }\end{array}$ & 3.38 & great extent \\
$\begin{array}{l}\text { How long do you stay online to have fun and relax (such as } \\
\text { watching movies, listening songs, playing games) in English? }\end{array}$ & 3.26 & great extent \\
How long do you stay online to write something in English? \\
$\quad$ General Weighted Mean
\end{tabular}


Legend

\section{Scale}

$5(4.3-5.0)=$ more than 5 hours

$4(3.5-4.2)=2$ to $5 \mathrm{hrs}$ a day

$3(2.7-3.4)=1$ to $2 \mathrm{hrs}$

$2(1.9-2.6)=$ about $60 \mathrm{mns}$

$1(1.0-1.8)=$ less than $30 \mathrm{mns}$

\section{Adjectival Description}

great extent

very great extent

moderate extent

limited extent

no extent

From the results in Table 2, it is easy to realize that the students do neither pay attention to improve their knowledge about ESL nor socialize with foreign contacts. They seemingly go on the Internet just for fun, not for self-study. In fact, when using the social networking sites for improving their English, concerning productive and receptive skills along with vocabulary/grammatical exercises, they feel only confident with reading skill 3.14, for other skills namely listening 1.84 , writing 1.69 , speaking 1.49 , and vocabulary/grammatical exercises 1.54. All of these are compared with the legend 0.1-0.9 nothing changeable; 1.0-1.9 less confident; 2.0-2.9 neutral; 3.0-3.9 confident, and 4.0-5.0 very confident. The general weighted mean is 1.94 , so it is concluded that the students felt less confident when using the social networking sites for their self-study in English.

For the students to encounter some problems when using the ICT in learning English, the findings revealed that they did not agree on the problems of not having any friends studying English together (1.49), poor internet connection (1.45), and lack of time for self-study (1.37). However, they claimed that they were not being guided how to exploit ICT (2.36) and followed by irrelevant materials (2.22) compared with the legend 1.0-1.6 agreed, 1.7-2.2 agreed, and 2.3-3.0 highly agreed.

By the way, the students also recognized the important role of using ICT in learning English when they were questioned. The students highly agreed that using ICT in learning English, they had more opportunity to learn English (2.65), had a good environment to improve English (2.62), and got instant support from the ICT, friends, teachers, ... while studying English (2.58). Besides, they also agreed that using ICT measured how they studied English (1.91) and the students felt more interested in learning English (2.03). These figures were compared with the legend 1-3 with not agreed, agreed, and highly agreed, respectively.

The Table 3 reveals the frequency of using the Internet for their self-study.

Table 3. The frequency of using the Internet for self-study.

\begin{tabular}{|c|c|c|}
\hline & Mean & Description \\
\hline $\begin{array}{l}\text { How often do you go online to search for information to do homework } \\
\text { and/or school assignment? }\end{array}$ & 1.91 & limited extent \\
\hline How often do you go online to post study questions? & 1.54 & no extent \\
\hline $\begin{array}{l}\text { How often do you go online to watch educational online classes/ } \\
\text { programs? }\end{array}$ & 1.68 & no extent \\
\hline $\begin{array}{l}\text { How often do you go online to exchange study related emails with } \\
\text { teachers and friends? }\end{array}$ & 1.65 & no extent \\
\hline How often do you go online to exchange personal emails with friends? & 3.31 & moderate extent \\
\hline How often do you go online to chat with your friends in English? & 1.96 & limited extent \\
\hline $\begin{array}{l}\text { How often do you go online to post pictures and to write stories on } \\
\text { social networks in English? }\end{array}$ & 2.01 & limited extent \\
\hline $\begin{array}{l}\text { How often do you go online to make new friends or meet new people } \\
\text { from other country using English? }\end{array}$ & 2.07 & limited extent \\
\hline $\begin{array}{l}\text { How often do you go online to download movies, TV series, songs, } \\
\text { and music videos for your lesson preparation? }\end{array}$ & 2.04 & limited extent \\
\hline How often do you go online to search for short courses in English? & 1.57 & no extent \\
\hline How often do you use social networking for collaborative learning? & 1.92 & limited extent \\
\hline $\begin{array}{l}\text { How often do you discuss homework with your friends using the } \\
\text { social networking? }\end{array}$ & 1.97 & limited extent \\
\hline How often do you update global news in English via English websites? & 2.65 & limited extent \\
\hline General Weighted Mean & 2.02 & limited extent \\
\hline
\end{tabular}

Legend

Scale Adjectival Description

Submit Date: 10.02. 2018, Acceptance Date: 27.02.2018, DOI NO: 10.7456/1080MSE/116

Research Article - This article was checked by Turnitin

Copyright (C) The Turkish Online Journal of Design, Art and Communication 
$5(4.3-5.0) \quad$ very great extent

$4(3.5-4.2) \quad$ great extent

$3(2.7-3.4) \quad$ moderate extent

$2(1.9-2.6) \quad$ limited extent

$1(1.0-1.8) \quad$ no extent

Sadly, the results in Table 3 reveal that they often exchange personal emails with their friends (3.31), however, they have limited, even no chances for other activities as the results from the table shown.

In order to know how the respondents remark on the utilization of ICT in learning English, they were surveyed and the outcome came up with that the respondents were not efficiently recognized the efficiency of exploiting the Internet (2.39). The legend was constructed with very efficiently, efficiently, neutral, not efficiently recognized, and not efficiently at all.

The last question on the survey was assessed the frequent contact between the students and the teachers to see how efficiently the teachers help their students in the self-study of learning English with the legend; very satisfactory, satisfactory, fair, not satisfactory, and very difficult to reach. The result showed that the respondents saw no satisfaction with their teachers' assistance in helping them improve their English via the digital learning (2.47).

The findings from the survey of the teachers.

For the teachers using the gadgets in social networking sites, they popularly use the laptops $50.0 \%$, then cellphones $40.9 \%$, and desktops $9.1 \%$. This might infer that laptops have wide screens and are easy to carry so that they seem to use the laptops most. For more information about the place the teachers did the social networking sites, the result came up with that the teachers usually visited them most at home $63.6 \%$, then at school $31.8 \%$, and very small figure $4.5 \%$ at Cyber Café. It can be deduced from the data that the teachers all have a good internet connection at home so they did not have to go to the Cyber Café for surfing the Internet. The table 4 shows the frequency that the teachers used the social networking sites.

Table 4. The frequency of the teachers' participation in the social networking sites.

\begin{tabular}{|c|c|c|}
\hline & Mean & Description \\
\hline Facebook & 3,55 & Often \\
\hline Twitter & 2.09 & Seldom \\
\hline LinkedIn & 3.59 & Often \\
\hline Google+ & 2.36 & Seldom \\
\hline Instagram & 3.41 & Sometimes \\
\hline Zalo & 3.68 & Often \\
\hline Skype & 2.27 & Seldom \\
\hline FB messenger & 3.68 & Often \\
\hline YouTube & 3.82 & Often \\
\hline Viber & 2.14 & Seldom \\
\hline Wechat & 2.09 & Seldom \\
\hline Yahoo & 1.86 & Never \\
\hline Line & 2.09 & Seldom \\
\hline General Weighted Mean & 2.82 & Sometimes \\
\hline
\end{tabular}

Legend

Scale Adjectival Description

$5(4.2-5.0) \quad$ Always

$4(3.5-4.2) \quad$ Often

$3(2.7-3.4) \quad$ Sometimes

$2(1.9-2.6) \quad$ Seldom

$1(1.0-1.8) \quad$ Never

From the data generated in the Table 4, it is clearly revealed that the teachers spent much time watching YouTube (3.82), followed by Zalo and FB messenger (3.68), then Facebook (3.55). It can be concluded that the teachers joined all kind of popular social networking sites, which caused no problems for them to get in touch with their students. 
It can be said that the teachers kept updated with social networking sites. They visited every day with at least once each day (63.6\%) and more than 5 times each day (36\%). For the duration of time they visited social networking sites, $36.4 \%$ of the teachers spent $4-5$ hours per day, then $27.3 \%$ for $3-4$ hours, $22.7 \%$ for $1-2$ hours, finally $13.6 \%$ for 5 hours and above. These figures are shown that the teachers were invested much time in doing the social networking sites.

Table 5 reveals the ways the teachers applied the digital learning and teaching.

Table 5. The means of using the industrial Internet in contacting the students

\begin{tabular}{|c|c|c|}
\hline & Mean & Description \\
\hline $\begin{array}{l}\text { How often do you use the social networking for delivering the } \\
\text { homework assignment? }\end{array}$ & 2.64 & limited extent \\
\hline How often do you assist students with self-study using the internet? & 2.18 & limited extent \\
\hline How often do you send short English courses to your students? & 2.14 & limited extent \\
\hline $\begin{array}{l}\text { How often do you check your student progress in English through } \\
\text { the internet? }\end{array}$ & 1.59 & no extent \\
\hline $\begin{array}{l}\text { How often do you organize any competitions in English using the } \\
\text { social networking? }\end{array}$ & 2.18 & limited extent \\
\hline $\begin{array}{l}\text { How often do you encourage your students to sit for online } \\
\text { international standardized English test such as TOEFL iBT, IELTS } \\
\text { or TOEIC? }\end{array}$ & 3.68 & great extent \\
\hline $\begin{array}{l}\text { How often do you converse English with your students in order to } \\
\text { enhance their English via the social networking? }\end{array}$ & 2.09 & limited extent \\
\hline $\begin{array}{l}\text { How often do you list the websites such as } \mathrm{BBC}, \mathrm{CNN}, \mathrm{VOA} \\
\text { news,... and divide your students in groups to create their own } \\
\text { activities for other groups to participate? }\end{array}$ & 2.45 & limited extent \\
\hline General Weighted Mean & 2.37 & moderate exten \\
\hline
\end{tabular}

Legend

Scale Adjectival Description

$5(4.3-5.0) \quad$ very great extent

$4(3.5-4.2) \quad$ great extent

$3(2.7-3.4) \quad$ moderate extent

$2(1.9-2.6) \quad$ limited extent

$1(1.0-1.8) \quad$ no extent

Disappointedly, the results in Table 5 showed that the teachers had limited extent or even no extent in finding the ways to utilize the industrial internet in teaching English. Only the way the teachers encouraged their students to take part in the international standardized English test such as TOEFL iBT, IELTS or TOEIC was remarkable with great extent.

Together with the attitude of the teachers to exploit the digital learning, some aspects of teaching English via the ICT were also put into consideration. The outcome came to the fact that the teachers' expectation to develop their students' ability is listening skill (3.68), listening skill (3.50), and vocabulary/grammatical exercises (3.91), all of these were with great extent. For other two skills namely reading skill (3.09) and writing skill (3.91), they were at moderate extent. These five elements belonged to the legend from one to five with the adjectival description; no extent, limited extent, moderate extent, great extent, and very great extent, respectively. Therefore, the teachers seemed to improve their students' communicative competence via the ICT.

The last item on the survey wanted to explore the assessment of the teachers in backing up the industrial internet in assisting their students. Surprisingly, opposite to the result from the table 5 above, the teachers believed that their affection to their students' self-study of English via the ICT was fair (2.82 out of the legend 5), which did not match with some opinions in the table 5.

\section{DISCUSSIONS}

The findings of the study also pointed out that the students did not have any problem with accessing the technology. Surprisingly, they used their time online to have fun and relax (such as watching movies, 
listening songs, playing games) in English but they did not spend time learning English via the digital technologies. The clear explanation for the reason why they did not feel interested in improving their English when online is that they did not receive much encouragement from their teachers in utilizing the Internet resources for their self-study. These findings are comparable with the results of a study conducted in Punjab University in India by Suri and Sharma (2013), a study by Achimugu, and Oluwagbemi, and Oluwaranti (2010), as well as with the outcomes of a study by Aixia, and Wang (2011). The assumption that the length of time that the students had access to the Internet affected their attitudes towards their self-study. This was found in the studies by Papaioannou, and Charalambous (2011), Sweeney, and Geer (2010) with the statement that the level of access to technology and its reliability influenced student intentions to use ICTs to support learning. However, the study showed that they did not pay their attention to the exploitation of the internet resources for their English improvement. In conclusion, the ability to use the Internet of the students was very good but the attitude for self-study English via the digital technologies was not high.

In terms of the teachers in this study, they were good at exploiting the technology during the course of their lessons in the classrooms. For some popular means of the social networking sites, the teachers spent so much time looking for the information relating the enhancement of their teaching English. It could be concluded that the concept of using the technology to teach SLA is not new not only in other countries but also in Vietnam. For Vietnamese circumstance, Dung (2006), Hoang (2015), Nha (2017), Trang (2017) and many other authors also emphasized the importance of using the digital learning in the self-study of the students especially learning English. Thanks to the Industry 4.0, Schawab (2016) confirmed that it would affect and be influenced by all countries, economies, sectors and people. Carvalho (2015), Haghshenas (2015), Pritchard (2007), Merino, and Lopez, and González (2010), and Bonanno (2010) emphasized the role of the ICT in the self-directed English learning via the Internet resources. From the finding of the study, it was deduced that the teachers failed to encourage and support English learners to enhance their self-study of English utilizing the virtual reality.

\section{CONCLUSIONS AND RECOMMENDATIONS}

From the findings of the study, a mismatch between the expectations of the students and the teachers in exploiting the Internet resources for the self-study of English is very clear. Although the ability and the accessibility to the Internet of them are very good, they have not found the best ways to meet the demands of their expectations. Both the teachers and the students spent much time on the Internet for entertainment, they all recognized the importance of using the internet resources in learning English. Actually, there are now many open digital learning technologies helping them to improve English thru the ICT.

There is a need to change the curricula in the schools to enhance the self-study of the students in SLA. The schools take advantage of the digital learning, encouraging the students to use the ICT by monitoring both the teachers and the students to use the industrial Internet for their teaching and learning English. There should be many campaigns, workshops, and competitions for the SLA organized widely in the school systems thanks to the social networking sites. The retrained skills for the teachers of managing the students' self-study in learning English should be paid attention. Besides, the teachers should be given a chance to recognize the role of themselves in self-directed learning by updating them with the latest information about the second language acquisition.

It is recommended that further researches should be done in recognizing the importance of utilizing the Internet resources in the self-directed English learning.

\section{REFERENCES}

Achimugu, P., Oluwagbemi, O., \& Oluwaranti, A. (2010). An evaluation of the impact of ICT diffusion in Nigeria's higher educational institutions. Journal of Information Technology Impact, 10(1), 25-34. Retrieved July 6, 2011 from http://www.jiti.net/v10/jiti.v10n1.025-034.pdf

Aixia, D., \& Wang, D. (2011). Factors influencing learner attitudes toward e-learning and development of elearning environment based on the integrated e-learning platform. International Journal of e-Education, $e$ Business, e-Management and e-Learning, 1(3), 264-268. Retrieved May 4, 2013 from http://www.ijeeee.org/Papers/043-Z0031.pdf

Allyson Eamer (2010). Language Teaching across the Digital Divide. In Technology Enhanced Learning: Quality of Teaching and Educational Reform, (pp. 36-41). Berlin: Springer. 
Alan Pritchard (2007). Effective Teaching with Internet Technologies. London: Paul Chapman Publishing Claus Pahl, Claire Kenny (2008). The Future of Technology Enhanced Active Learning: A Roadmap. In Technology Enhanced Learning: Best Practices, (pp. 348-374). New York: IGI Publishing.

David C. Merino, Enric S. Lopez, Inés G. González (2010). Which Are the Determinants of Online Students' Efficiency in Higher Education? In Technology Enhanced Learning: Quality of Teaching and Educational Reform, (pp. 209-215). Berlin: Springer.

Elizabeth Sherly, Md. Meraj Uddin (2010). A Technology Enhanced Learning Model for Quality Education. In Technology Enhanced Learning: Quality of Teaching and Educational Reform, (pp. 446-451). Berlin: Springer.

Earle, R. S. (2002). The integration of instructional technology into public education: Promises and challenges. Educational Technology Magazine, 42(1), 5-13.

Frieda Charalabopoulou (2010). TELL (Technology-Enhanced Language Learning) and Less-Commonly Taught Languages: The Case of Modern Greek. In Technology Enhanced Learning: Quality of Teaching and Educational Reform, (pp. 156-163). Berlin: Springer.

Goldber, H. R., \& McKhann, G. M. (2000, June). Student test scores are improved in a virtual learning environment, Advances in Physiology Education, 23(1), 59-66.

Goran Shimic, (2008). Technology Enhanced Learning Tools. In Technology Enhanced Learning: Best Practices, (pp. 1-27). New York: IGI Publishing.

Hoang Nguyen Thu Trang (2017). What do learners of technology say about self-directed English learning with technology? Retrieved from https://js.vnu.edu.vn/FS/article/view/4133/3852

http://www.seameo.org/SEAMEOWeb2/images/stories/Publications/Project_Reports/SEAMEO_ICT-

Integration-Education2010.pdf

https://www.vietnambreakingnews.com/2016/02/educator-training-key-to-optimising-technology-in-

classrooms-in-asia-pacific-microsoft-survey/

Kumar, A., Pakala, R., Ragade, R. K., \& Wong, J. P. (1998). The virtual learning environment system. Proceedings of the Frontiers in Education Conference, 2, 711-716.

Luísa Margarida Cagica Carvalho (2015). Challenges and Opportunities for Virtual Universities in the $21^{\text {st }}$ Century. In Assessing the Role of Mobile Technologies and Distance Learning in Higher Education, (pp. 133-146). Information Science Reference (an imprint of IGI Global).

Le Roux, C. J. B., \& Evans, N. (2011). Can cloud computing bridge the digital divide in South African secondary education? Information Development, 27(2), 109-116.

Likert, R. (1932). A Technique for the Measurement of Attitudes. Archives of Psychology, 140, 1-55.

Marzano, R. J. (2003b). What works in schools: Translating research into action. Alexandria, VA: Association for Supervision and Curriculum Development.

M. Haghshenas, A. Sadeghzadeh, R. Shahbazi, M. Nassiriyar (2015). Mobile Wireless Technologies Application in Education. In Assessing the Role of Mobile Technologies and Distance Learning in Higher Education, (pp. 311-331). Information Science Reference (an imprint of IGI Global).

Nguyen Kim Dung (2006). Application of information technology in training programs. Retrieved from http://www.ier.edu.vn/ung-dung-cong-nghe-thong-tin-trong-chuong-trinh-dao-tao.html

Nguyen Van Long (2016). IT Application In Foreign Language Education: From International Experience to Real State of Affairs in Vietnam. Retrieved from https://js.vnu.edu.vn/ER/article/view/1670/1609

Parkay, F., Anctil, E. J., \& Hass, G. (2010). Curriculum leadership: Readings for developing quality educational programs (9th ed.). Boston, MA: Allyn \& Bacon

Phung Xuan Nha (2017). Directive on Major Tasks of the 2016-2017 period education. Retrieved from https://thuvienphapluat.vn/van-ban/Giao-duc/Chi-thi-3031-CT-BGDDT-nhiem-vu-chu-yeu-nam-hoc-20162017-321432.aspx

Philip Bonanno (2010). A Process-Oriented Model for Technology-Enhanced Learning. In Technology Enhanced Learning: Quality of Teaching and Educational Reform, (pp. 525-533). Berlin: Springer.

Papaioannou, P., \& Charalambous, K. (2011). Principals' attitudes towards ICT and their perceptions about the factors that facilitate or inhibit ICT integration in primary schools of Cyprus. Journal of Information Technology Education, 10, 349-369. Retrieved May 4, 2013 from http://www.jite.org/documents/Vollo/JITEv10p349-369Papaioannou958.pdf

Ricardo C. Palacios, Fernando P. Martın, Angel G. Crespo, Belen R. Mezcua (2010). Technology Enhanced Learning for People with Intellectual Disabilities and Cerebral Paralysis: The MAS Platform. In Technology Enhanced Learning: Quality of Teaching and Educational Reform, (pp. 11-17). Berlin: Springer. 
Sweeney, T., \& Geer. R. (2010). Student capabilities and attitudes towards ICT in the early years. Australian Educational Computing, 25(2010), 18-24. Retrieved May 5, 2013 from http://acce.edu.au/sites/acce.edu.au/files/pj/journal/AEC Vol 25 No IStudentCapabilities.pdf Suri, G., \& Sharma, S. (2013). The impact of gender on attitude towards computer technology and $e$ learning: An exploratory study of Punjab University, India. International Journal of Engineering Research, 2(2), 132-136. Retrieved May 31, 2013 from http://www.ijer.in/ijer/publication/v2s2/paper22.pdf

$\mathrm{Vu}$ Ngoc Hoang (2015). Information technology and innovation, educational development. Retrieved $22^{\text {nd }}$ January 2015 from http://dangcongsan.vn/doi-moi-can-ban-va-toan-dien-giao-duc-dao-tao/dien-dan/congnghe-thong-tin-va-doi-moi-phat-trien-giao-duc-347592.html 